Check for updates

Cite this: RSC Adv., 2018, 8, 18663

Received 21st March 2018

Accepted 14th May 2018

DOI: $10.1039 / \mathrm{c} 8 \mathrm{ra02467g}$

rsc.li/rsc-advances

\section{Silicalite-1 zeolite acidification by zinc modification and its catalytic properties for isobutane conversion $\dagger$}

\author{
Guodong Liu, (D) ${ }^{a}$ Jiaxu Liu, (DD ${ }^{a}$ Ning He, ${ }^{a}$ Cuilan Miao, ${ }^{a}$ Jilei Wang, ${ }^{a}$ Qin Xin ${ }^{b}$ \\ and Hongchen Guo*a
}

A series of $\mathrm{Zn}$-modified Silicalite-1 (S-1) zeolites $\left(\mathrm{Zn}_{x} / \mathrm{S}-1\right)$ were prepared by the wetness-impregnation method and applied in the catalytic conversion of isobutane. The structure and location of $\mathrm{Zn}$ species in $\mathrm{Zn}_{x} / \mathrm{S}-1$ were investigated using UV-Vis and $\mathrm{N}_{2}$ physical adsorption. The acidity and origin of the acid sites in $\mathrm{Zn}_{x} / \mathrm{S}-1$ were studied by $\mathrm{NH}_{3}$-temperature programmed desorption and Fourier-transform infrared analysis. The catalytic performance of $\mathrm{Zn}_{x} / \mathrm{S}-1$ for isobutane conversion was investigated in a fixed-bed microreactor. In the experiments, the acidity of S-1 zeolite was dramatically increased by modification with Zn, with both Lewis and Brønsted sites identified in $Z n_{x} / S-1$. The relationship between Brønsted acid sites and $\mathrm{Zn}-\mathrm{OH}$ groups on $\mathrm{ZnO}$ clusters of $\mathrm{Zn} \mathrm{n}_{x} / \mathrm{S}-1$ was also revealed for the first time. Furthermore, $Z_{x} / S-1$ catalysts exhibited excellent catalytic performances in both isobutane dehydrogenation and butene isomerization reactions. A high selectivity of total butene products ranging from 84.6 to 97.2 was achieved on the catalysts with different $\mathrm{Zn}$ loadings. Moreover, the linear correlation between isobutane conversion and the acid amount (determined by $\mathrm{NH}_{3}-\mathrm{TPD}$ ) confirmed that the weak-to-medium acid sites in $\mathrm{Zn}_{x} / \mathrm{S}-1$ should play a key role in isobutane conversion.

\section{Introduction}

Silicalite-1 (S-1) zeolite is an aluminum-free crystalline silicate with the same MFI topological framework as the Al-containing ZSM-5 zeolite. Generally, crystalline S-1 zeolites are chemically inert because their interior structure contains only unreactive siloxane (Si-O-Si) bridges. ${ }^{1}$ The presence of defective sites in their lattice can facilitate the formation of weak acidic centers (derived from silanol groups), which have been reported as active Beckmann rearrangement catalysts. ${ }^{2-4}$ Although the amount of weak acid sites and, to some extent, the acidic strength of S-1 zeolite can be modulated by changing the crystallization conditions or through post-synthesis treatment, ${ }^{2,5,6}$ its catalytic properties remain limited. In contrast, ZSM-5 is a strongly acidic zeolite that can catalyze several reactions, including olefin oligomerization, aromatic alkylation, toluene disproportionation, methanol-to-hydrocarbon conversions (including MTG, MTO, MTP), and light hydrocarbon cracking

${ }^{a}$ Department of Catalytic Chemistry and Engineering, State Key Laboratory of Fine Chemicals, Dalian University of Technology, Dalian 116012, P. R. China. E-mail: hongchenguo@dlut.edu.cn

${ }^{b}$ State Key Laboratory of Catalysis, Dalian Institute of Chemical Physics, Chinese Academy of Sciences, Dalian 116023, P. R. China

$\dagger$ Electronic supplementary information (ESI) available: XRF, SEM and TEM images, $\mathrm{N}_{2}$ adsorption and desorption isotherms, the relative crystallinity of catalysts, XRD patterns, the acid amount of catalysts. See DOI: 10.1039/c8ra02467g and aromatization..$^{7-11}$ This clearly indicates that the acidity of S1 zeolite needs to be increased to broaden its catalytic applications.

The conversion of light alkanes, such as propane and isobutane, into their corresponding value-added alkenes has received much attention. Currently, $\mathrm{Pt} / \mathrm{Al}_{2} \mathrm{O}_{3}$ and $\mathrm{Cr}_{x} \mathrm{O}_{3} / \mathrm{Al}_{2} \mathrm{O}_{3}$ catalysts are employed industrially to produce propylene and isobutene from the non-oxidative dehydrogenation of propane and isobutane, respectively. ${ }^{12}$ However, these catalysts have drawbacks because $\mathrm{Pt}$ is expensive and has limited availability, while $\mathrm{Cr}_{x} \mathrm{O}_{3} / \mathrm{Al}_{2} \mathrm{O}_{3}$ is not environmentally friendly owing to its toxicity. ${ }^{13}$ Therefore, the development of novel catalysts with superior catalytic efficiency for light alkane non-oxidative dehydrogenation is highly desirable. It has been accepted that Zn-containing catalysts were active in the dehydrogenation of alkanes. ${ }^{14-16,19-21}$ Zn-modified HZSM-5 zeolites (Zn/ZSM-5) have been reported to be effective catalysts for low-temperature activation of light alkanes, with the modified Zn species playing a key role in light alkane dehydrogenation. ${ }^{14-16}$ However, their commercial use in such processes is impeded by their poor alkene selectivity with respect to the formation of large amounts of cracked dry gas byproducts $\left(\mathrm{C}_{1}\right.$ and $\mathrm{C}_{2}$ hydrocarbons), resulting from the strong acidic character of HZSM-5 zeolite. ${ }^{17,18}$ Moreover, zinc titanate catalysts in the form of hydrogels or mixed oxides have also been mentioned in the dehydrogenation of light alkanes. ${ }^{19,20}$ Zinc titanate is an environmentally friendly material and of low cost. However, the overall activity of the 
catalyst was found to be limited or the selectivity declined rapidly as a function of reaction time. Recently, isolated $\mathrm{Zn}^{2+}$ species deposited on a silica support were found to be active in propane dehydrogenation. ${ }^{21}$ The high propylene selectivity was attributed to the absence of Brønsted acid sites on the $\mathrm{Zn} / \mathrm{SiO}_{2}$ catalyst. However, the catalyst is not so stable enough that its activity only remained half of the initial activity in $12 \mathrm{~h}$.

The activation of propane over Zn-modified S-1 zeolite (denoted as $\mathrm{Zn} / \mathrm{S}-1$ ) has been studied by employing in situ ${ }^{13} \mathrm{C}$ MAS NMR and IR spectroscopic techniques in $2006 .{ }^{15}$ It was proposed that propane was activated through dissociative adsorption over zinc oxide species, followed by propene evolution and recombinative desorption of dihydrogen. On the other hand, the acidity of Zn-modified HZSM-5 zeolite (Zn/HZSM-5) was reported to play a key role in the transformation of light alkanes. However, few study related to the effect of acid sites of $\mathrm{Zn} / \mathrm{S}-1$ on alkane dehydrogenation was reported, probably because the acidity of $\mathrm{S}-1$ zeolite is negligible compared with that of HZSM-5 zeolite. Moreover, the influence of $\mathrm{Zn}$ modification on the acidity of S-1 zeolite and the role of these acid sites in light alkane conversion is yet unclear. Therefore, a series of Zn-modified S-1 catalysts was prepared in this work. The acidity and origin of acidity of these $\mathrm{Zn} / \mathrm{S}-1$ catalysts were characterized by $\mathrm{NH}_{3}$-temperature programmed desorption (TPD) and Fourier-transform infrared (FT-IR) spectroscopy analysis. Furthermore, the catalytic properties of these $\mathrm{Zn} / \mathrm{S}-1$ catalysts in isobutane conversion were investigated using a fixed-bed microreactor.

\section{Experimental}

\subsection{Catalyst preparation}

S-1 zeolite was synthesized according to a reported procedure for the synthesis of TS- $1,{ }^{22}$ except that no titanium source was used. Typically, tetraethyl orthosilicate (TEOS; Sinopharm Chemical Reagent Co., Ltd), tetrapropylammonium hydroxide (TPAOH; 25 wt\% aqueous solution, Sinopharm), and distilled deionized water were mixed to form a clear solution with a $\mathrm{SiO}_{2} /$ $\mathrm{TPAOH} / \mathrm{H}_{2} \mathrm{O}$ ratio of $1: 0.3: 30$. The solution was hydrolyzed at $60{ }^{\circ} \mathrm{C}$ in a water bath for $3 \mathrm{~h}$ with magnetic stirring to give a homogeneous sol that was then transferred to a Teflon-lined autoclave and crystallized at $170{ }^{\circ} \mathrm{C}$ for $24 \mathrm{~h}$. The assynthesized precipitate was collected by filtration, washed several times with deionized water, and dried at $110{ }^{\circ} \mathrm{C}$ overnight. The zeolite products were then calcined at $550{ }^{\circ} \mathrm{C}$ for $6 \mathrm{~h}$ for further characterization or use.

Zn-modified zeolite catalysts were prepared using a wetnessimpregnation method. The calcined S-1 zeolite was impregnated with an aqueous solution of $\mathrm{Zn}\left(\mathrm{NO}_{3}\right)_{2} \cdot 6 \mathrm{H}_{2} \mathrm{O}$ (Sinopharm Chemical Reagent Co., Ltd) in a water bath at $80{ }^{\circ} \mathrm{C}$ for $3 \mathrm{~h}$. The impregnated zeolite was then dried at $110{ }^{\circ} \mathrm{C}$ for $12 \mathrm{~h}$ and calcined at $550{ }^{\circ} \mathrm{C}$ for $6 \mathrm{~h}$ to obtain the $\mathrm{Zn} / \mathrm{S}-1$ samples. The desired $\mathrm{Zn}$ loadings were achieved by adjusting aqueous solution of $\mathrm{Zn}\left(\mathrm{NO}_{3}\right)_{2} \cdot 6 \mathrm{H}_{2} \mathrm{O}$ with the appropriate concentration. The modified S-1 zeolites with different $\mathrm{Zn}$ loadings were denoted as $\mathrm{Zn}_{x} / \mathrm{S}-1$, where $x$ is the $\mathrm{Zn}$ loading amount in $\mathrm{wt} \%$. For comparative catalytic tests in isobutane conversion, a $6.0 \mathrm{wt} \%$
Zn-modified HZSM-5 zeolite (crystal size, 100-200 nm; $\mathrm{SiO}_{2}$ / $\mathrm{Al}_{2} \mathrm{O}_{3}$ molar ratio, $26: 1$ ) was also prepared using the same impregnation method (denoted as $\mathrm{Zn}_{6.0} / \mathrm{ZSM}-5$ ).

\subsection{Catalyst characterization}

Powder X-ray diffraction (XRD) patterns were collected on a Rigaku D/max-2004 diffractometer with a $\mathrm{Cu} \mathrm{K} \alpha$ radiation source $(40 \mathrm{kV}, 100 \mathrm{~mA})$. Measurements were conducted in the $2 \theta$ range of $5-80^{\circ}$ with a scanning speed of $2^{\circ} \mathrm{min}^{-1}$. X-Ray Fluorescence spectrometry (XRF) was conducted on a Bruker SRS 3400 instrument. Field emission scanning electron microscopy (FE-SEM) images of crystal morphologies were obtained using a Hitachi S-4800 microscope. The distribution of $\mathrm{Zn}$ species on the modified catalysts was examined by UV-Vis spectrophotometry, conducted on a JASCO V-550 spectrometer with $\mathrm{BaSO}_{4}$ as the reference. High resolution transmission electron microscopy (HRTEM) measurements were taken on a JEM$2100 \mathrm{~F}$ electron microscope with an acceleration voltage of 200 $\mathrm{kV}$.

$\mathrm{N}_{2}$ physical adsorption-desorption isotherms were measured on a Micromeritics ASAP 2020 instrument at $-196^{\circ} \mathrm{C}$ to determine the textural properties. Prior to measurement, the samples (sieve fraction, 380-830 $\mu \mathrm{m}$ ) were degassed under vacuum at $350{ }^{\circ} \mathrm{C}$ for $6 \mathrm{~h}$. The specific surface area was calculated by the Brunauer-Emmett-Teller (BET) method using the adsorption branch in the $P / P_{0}$ range $0.10-0.15$. The pore volumes were estimated at the $P / P_{0}$ point of 0.99 . The microporosity and mesoporosity of the samples was discriminated using the $t$-plot method.

$\mathrm{NH}_{3}$-TPD was performed on a Quantachrome ChemBet 3000 chemisorb instrument to investigate the total acidity of the catalysts. Sample pellets (150 mg; sieve fraction, 380-830 $\mu \mathrm{m}$ ) were pretreated under helium $(\mathrm{He})$ at $600{ }^{\circ} \mathrm{C}$ for $1 \mathrm{~h}$. After cooling to $100{ }^{\circ} \mathrm{C}$, a mixed gas of $5 \% \mathrm{NH}_{3}$ in He was passed through the catalyst bed to allow ammonia adsorption for $30 \mathrm{~min}$. The cell was then purged with He flow $\left(50 \mathrm{~mL} \mathrm{~min}{ }^{-1}\right)$ for 30 min to remove all $\mathrm{NH}_{3}$ not chemically adsorbed. The $\mathrm{NH}_{3}$ TPD profiles were recorded by heating the cell to $600{ }^{\circ} \mathrm{C}$ at a ramping rate of $16{ }^{\circ} \mathrm{C} \mathrm{min}{ }^{-1}$.

FT-IR of adsorbed $\mathrm{NH}_{3}$ (FT-IR- $\mathrm{NH}_{3}$ ) was used to determine the Lewis and Brønsted acidities of the catalysts. FT-IR- $\mathrm{NH}_{3}$ spectra were collected on a Nicolet 6700 FT-IR spectrometer ( $4 \mathrm{~cm}^{-1}$ optical resolution with one level of zero-filling for the Fourier transform). First, about $15 \mathrm{mg}$ of sample was pressed into a self-supporting wafer (diameter, $13 \mathrm{~mm}$ ) and then treated in a cuvette in situ under vacuum $\left(10^{-3} \mathrm{~Pa}\right)$ at $400{ }^{\circ} \mathrm{C}$ for $4 \mathrm{~h} . \mathrm{NH}_{3}$ adsorption was conducted with admittance of an ammonia flow of $30 \mathrm{~mL} \mathrm{~min} \min ^{-1}$ into the cuvette for $30 \mathrm{~min}$ at ambient temperature. The wafer was then subjected to vacuum treatment at 150,300 , and $450{ }^{\circ} \mathrm{C}$ for $30 \mathrm{~min}$ each. Finally, the measured spectra were collected.

To determine the catalyst acidity of the surface hydroxyl groups, FT-IR spectra of surface hydroxyl groups with ammonia absorption (OH-FT-IR- $\mathrm{NH}_{3}$ ) were recorded using a Nicolet iS10 FT-IR spectrometer. The samples were pressed into selfsupporting thin wafers (approximately $15 \mathrm{mg}$ ) and 

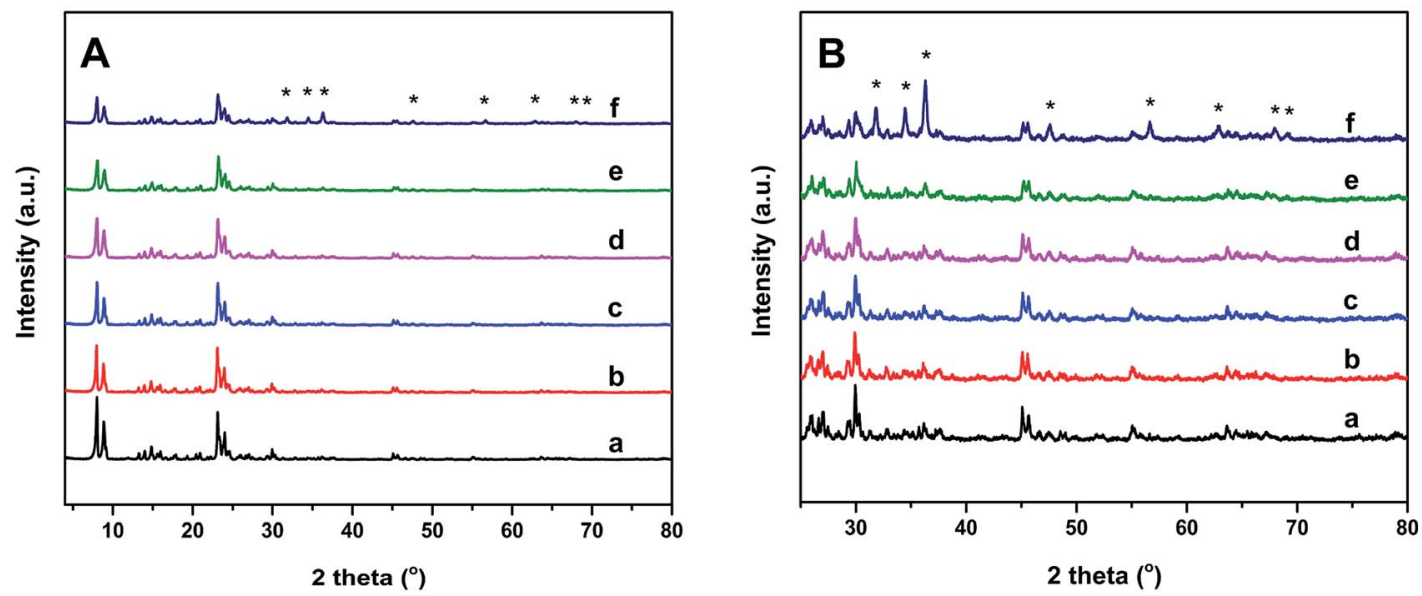

Fig. 1 XRD patterns (A) and the magnified patterns (B) of S-1 (a), Zn $\mathrm{n}_{1.0} / \mathrm{S}-1$ (b), Zn $\mathrm{n}_{3.0} / \mathrm{S}-1$ (c), $Z \mathrm{n}_{6.0} / \mathrm{S}-1$ (d), $Z \mathrm{n}_{8.0} / \mathrm{S}-1$ (e) and $Z \mathrm{n}_{12.0} / \mathrm{S}-1$ (f). (The asterisk labels show the diffraction peaks of $\mathrm{ZnO}$ crystal with wurtzite structure).

decontaminated at $400{ }^{\circ} \mathrm{C}$ under vacuum $\left(10^{-3} \mathrm{~Pa}\right)$ for $4 \mathrm{~h}$ in a quartz IR cell equipped with $\mathrm{CaF}_{2}$ windows. An ammonia gas stream $\left(30 \mathrm{~mL} \mathrm{~min}{ }^{-1}\right)$ was passed through the sample cell at $150{ }^{\circ} \mathrm{C}$ for $30 \mathrm{~min}$ to allow ammonia adsorption. Evacuation treatment $\left(10^{-3} \mathrm{~Pa}\right)$ was conducted for $30 \mathrm{~min}$ at the same temperature. After cooling to room temperature, OH-FT-IR-NH spectra were recorded by subtracting the blank background spectrum (recorded using an empty IR cell without sample). Spectra were recorded in the range $4000-400 \mathrm{~cm}^{-1}$ with a resolution of $4 \mathrm{~cm}^{-1}$.

\subsection{Catalytic tests}

Isobutane conversion tests were performed in a fixed-bed microreactor (i.d., $6 \mathrm{~mm}$ ) under atmospheric pressure. The catalyst loading for each run was about $200 \mathrm{mg}$. Prior to activity tests, catalysts $\left(d_{\mathrm{p}}=20-40\right.$ mesh) were activated in situ at $550{ }^{\circ} \mathrm{C}$ for $1 \mathrm{~h}$ under nitrogen flow, and then prereduced under $5 \% \mathrm{H}_{2}$ in $\mathrm{N}_{2}$ gas flow $\left(50 \mathrm{~mL} \mathrm{~min}^{-1}\right.$, standard temperature and pressure) at $500{ }^{\circ} \mathrm{C}$ for $30 \mathrm{~min}$. The isobutane feedstock was diluted with nitrogen (employed as a calibrating gas) to give a $50: 50(\mathrm{v} /$ v) mixture. The flow rates of isobutane and nitrogen were controlled separately using mass flow meters. For catalytic activity tests, the mixing gas was fed at a gas hourly space velocity (GHSV) of about $1200 \mathrm{~h}^{-1}$, with the reaction conducted at $550{ }^{\circ} \mathrm{C}$ and atmospheric pressure. Effluent hydrocarbon products were analyzed using on-line gas chromatography (GC; Shimadzu GC-14B, OV-1 capillary column $50 \mathrm{~m} \times 0.20 \mathrm{~mm}$, flame ionization detector).

The isobutane conversion ( $\left.C_{\text {isobutane }}\right)$ and product selectivity $\left(S_{\mathrm{i}}\right)$ were calculated using the following equations:

$$
\begin{gathered}
C_{\text {isobutane }}=\left(\sum A_{\mathrm{i}}-A_{\text {isobutane }}\right) / \sum A_{\mathrm{i}} \times 100 \% \\
S_{\mathrm{i}}=A_{\mathrm{i}} /\left(\sum A_{\mathrm{i}}-A_{\text {isobutane }}\right) \times 100 \%
\end{gathered}
$$

where $A_{\mathrm{i}}$ and $A_{\text {isobutane }}$ are the corrected chromatographic areas of a specific compound and residual isobutane, respectively.

\section{Results and discussion}

\subsection{Catalyst characterization}

SEM, XRD, and $\mathrm{N}_{2}$ physical adsorption-desorption isotherms were measured to assess the effect of the $\mathrm{Zn}$ dopant on the structures of the $\mathrm{Zn}_{x} / \mathrm{S}-1$ catalysts. The SEM images (see Fig. S1 $\dagger$ ) showed that the mean size of parent S-1 zeolite was around $100 \mathrm{~nm}$. The introduction of Zn species by impregnation has little influence on the crystal size and the morphology of parent S- 1 zeolite. Structural changes in $\mathrm{Zn}_{x} / \mathrm{S}-1$ catalysts were also analyzed using XRD patterns. As shown in Fig. 1, five characteristic diffraction peaks of MFI structure were found at $2 \theta=7.9,8.8,23.1,23.8$ and 24.3 in all catalysts. No diffraction signal for $\mathrm{Zn}$ species was observed at $\mathrm{Zn}$ content below $8.0 \mathrm{wt} \%$, indicating that Zn species were highly dispersed. Nevertheless, characteristic peaks of the $\mathrm{ZnO}$ phase with a wurtzite structure ${ }^{23}$ (denoted with asterisks in Fig. 1A and B) were presented in $\mathrm{Zn}_{12.0} / \mathrm{S}-1$. When the amount of $\mathrm{Zn}$ added was too high, $\mathrm{Zn}$ species seemed not to be uniformly dispersed in the zeolite channels, but formed large wurtzite-structured ZnO particles on the zeolite surface. The average particle size of $\mathrm{ZnO}$ particles was estimated to be $4.8 \mathrm{~nm}$ by using the Scherrer's equation. Fig. S2 $\uparrow$ shows the HRTEM images of $\mathrm{Zn}_{6.0} / \mathrm{S}-1$ and $\mathrm{Zn}_{12.0} / \mathrm{S}-1$ catalysts. There are a number of $\mathrm{ZnO}$ particles reside on the external surface of $\mathrm{Zn}_{12.0} / \mathrm{S}-1$ catalyst, while no clear pattern of $\mathrm{ZnO}$ particles has been observed on the outside surface of $\mathrm{Zn}_{6.0} /$ S-1. Moreover, in comparison with parent S-1 zeolite, the relative crystallinity of $\mathrm{Zn}_{x} / \mathrm{S}-1$ catalysts gradually decreased (see Table S2 $\dagger$ ), which was probably attributed to the high X-ray absorption coefficient of impregnated metal species. ${ }^{24,25}$ The textural properties of $\mathrm{Zn}_{x} / \mathrm{S}-1$ catalysts were determined from $\mathrm{N}_{2}$ physical adsorption-desorption, as summarized in Table 1. At low $\mathrm{Zn}$ loadings ( $1.0 \mathrm{wt} \%$ and $3.0 \mathrm{wt} \%$ ), the specific surface area of $\mathrm{Zn}_{x} / \mathrm{S}-1$ decreased slightly with increasing $\mathrm{Zn}$ loading. This indicated that subnanometric $\mathrm{ZnO}$ clusters inside the zeolitic pores or channels only had a small effect on the textural properties of the S-1 zeolite. However, at high Zn loadings (above 
Table $1 \mathrm{~N}_{2}$ adsorption-desorption data of $Z n_{x} / S-1$ catalysts

\begin{tabular}{|c|c|c|c|c|c|c|}
\hline $\begin{array}{l}\text { Zn loading } \\
\text { (wt\%) }\end{array}$ & $S_{\text {BET }}\left(\mathrm{m}^{2} \mathrm{~g}^{-1}\right)$ & $S_{\text {Micro }}\left(\mathrm{m}^{2} \mathrm{~g}^{-1}\right)$ & $S_{\text {extern }}\left(\mathrm{m}^{2} \mathrm{~g}^{-1}\right)$ & $V_{\text {pores }}\left(\mathrm{cm}^{3} \mathrm{~g}^{-1}\right)$ & $V_{\text {micro }}\left(\mathrm{cm}^{3} \mathrm{~g}^{-1}\right)$ & $V_{\text {meso }}\left(\mathrm{cm}^{3} \mathrm{~g}^{-1}\right)$ \\
\hline 0.0 & 390 & 239 & 150 & 0.27 & 0.11 & 0.16 \\
\hline 3.0 & 370 & 228 & 141 & 0.26 & 0.10 & 0.15 \\
\hline 6.0 & 325 & 245 & 80 & 0.20 & 0.10 & 0.10 \\
\hline 8.0 & 290 & 217 & 72 & 0.20 & 0.10 & 0.10 \\
\hline
\end{tabular}

$6.0 \mathrm{wt} \%$ ), the specific surface area of $\mathrm{Zn}_{x} / \mathrm{S}-1$ declined rapidly with increasing $\mathrm{Zn}$ loading, mainly due to decreases in external surface area (from $150 \mathrm{~m}^{2} \mathrm{~g}^{-1}$ to $72 \mathrm{~m}^{2} \mathrm{~g}^{-1}$ ) and mesoporosity (from $0.16 \mathrm{~m}^{3} \mathrm{~g}^{-1}$ to $0.10 \mathrm{~m}^{3} \mathrm{~g}^{-1}$ ). Furthermore, the microstructure characteristics were slightly disrupted. These data showed that large $\mathrm{ZnO}$ particles were mainly deposited on the external surface and blocked mesopore openings in S-1 zeolite.

UV-Vis spectra of $\mathrm{Zn}_{x} / \mathrm{S}-1$ catalyst are shown in Fig. 2. Generally, the modification of S-1 with $\mathrm{Zn}$ leads to the appearance of two new bands at about 265 and $365 \mathrm{~nm}$, corresponding to subnanometric $\mathrm{ZnO}$ clusters inside zeolitic pores and large ZnO crystals on the external zeolite surface, respectively. ${ }^{15,23}$ For $\mathrm{Zn}_{1.0} / \mathrm{S}-1$ and $\mathrm{Zn}_{3.0} / \mathrm{S}-1$ samples, the band at $265 \mathrm{~nm}$ was significant, while the band at $365 \mathrm{~nm}$ was almost nonexistent, suggesting that the two catalysts mainly comprised subnanometric $\mathrm{ZnO}$ clusters. In contrast, both bands were present in samples with $\mathrm{Zn}$ loadings above $6.0 \mathrm{wt} \%$. Increasing $\mathrm{Zn}$ loading in these catalysts enhanced both bands, with the intensity of the band at $365 \mathrm{~nm}$ increasing much faster. These observations showed that the $\mathrm{Zn}_{x} / \mathrm{S}-1$ samples with higher $\mathrm{Zn}$ loadings $(x=6.0-12.0)$ contained not only $\mathrm{ZnO}$ clusters inside S-1 zeolitic pores, but also large ZnO crystals located on the external surface. The increased $\mathrm{Zn}$ loading mainly facilitated the formation of large $\mathrm{ZnO}$ crystals.

\subsection{Acidity enhancement by $\mathrm{Zn}$ modification}

The acid amount and strength of S-1 and Zn-modified sample $\mathrm{Zn}_{6.0} / \mathrm{S}-1$ were investigated using $\mathrm{NH}_{3}$-TPD. For comparison, the acidities of HZSM-5 $\left(\mathrm{SiO}_{2} / \mathrm{Al}_{2} \mathrm{O}_{3}\right.$ molar ratio, $\left.26: 1\right)$ and $\mathrm{Zn}_{6.0} /$ HZSM-5 were also tested. As shown in Fig. 3A, the whole $\mathrm{NH}_{3}$ desorption profile for the parent $\mathrm{S}-1$ zeolite was approximately a straight line. Almost no $\mathrm{NH}_{3}$ molecules were adsorbed on S-1, demonstrating its weak acidic character compared with that of HZSM-5. Notably, the $\mathrm{NH}_{3}$ desorption peak of the $\mathrm{Zn}_{6.0} / \mathrm{S}-1$ sample was quite strong, although the acid amount remained much lower than that of HZSM-5 and $\mathrm{Zn}_{6.0} / \mathrm{HZSM}-5$. This clearly showed that impregnation with $\mathrm{Zn}$ significantly enhanced the acidity of the S-1 zeolite. We also compared the $\mathrm{NH}_{3}$-TPD profiles of the $\mathrm{Zn}_{x} / \mathrm{S}-1$ catalysts, which exhibited two distinct desorption peaks at 267 and $375{ }^{\circ} \mathrm{C}$ (see Fig. 3B), corresponding to weak and medium acidic sites, respectively. Furthermore, it was also feasible to gradually increase the amount of acid sites in the S-1 zeolite by increasing the loading of $\mathrm{Zn}$ until the maximum value was reached, as shown in Fig. 4. Detailed information on the calculated statistical results of acid amount is shown in Table S3. $\uparrow$ For the parent S-1 used herein, the maximum $\mathrm{Zn}$ loading was around 6.0-8.0 wt\%. When the $\mathrm{Zn}$ loading was low (below $3.0 \%$ ), the increase in $\mathrm{Zn}$ loading dramatically increased the acidity of the S-1 zeolite. However, when the $\mathrm{Zn}$ loading was high (in the range 3.0-8.0 $\mathrm{wt} \%$ ), the overall acid amount in the modified S-1 zeolite reached its maximum value, with the increasing trend with $\mathrm{Zn}$ loading becoming marginal.

The acidity of $\mathrm{Zn}_{x} / \mathrm{S}-1$ zeolites was further studied using ammonia-adsorbed FT-IR spectra. As shown in Fig. 5A, the strong absorption peak at $1620 \mathrm{~cm}^{-1}$ was attributed to asymmetric deformation of ammonia coordinated to Lewis acid sites, which usually appears in the bending vibration region of $1700-1300 \mathrm{~cm}^{-1}$ and indicates that $\mathrm{Zn}$ modification resulted in the formation of an appreciable amount of Lewis acid sites in $\mathrm{Zn}_{x} / \mathrm{S}-1 .^{26-29}$ The variation trend in the intensity of this peak was in agreement with the change in the $\mathrm{NH}_{3}$-TPD results. However, the existence of Brønsted acid sites in $\mathrm{Zn}_{x} / \mathrm{S}-1$ required further confirmation because the IR bands corresponding to ammonium ion deformation vibrations were obscure. In contrast, as shown in Fig. 5A and the magnified range of $3500-3000 \mathrm{~cm}^{-1}$ in Fig. 5B, in addition to the apparent bands in the range 3350$3200 \mathrm{~cm}^{-1}$, which were attributed to ammonia coordination on Lewis acid sites, two weak yet clear absorption peaks at 3220 and $3190 \mathrm{~cm}^{-1}$ emerged in the $\mathrm{N}-\mathrm{H}$ stretching region. ${ }^{26,28}$ It was clear that Zn modification not only produced a number of Lewis

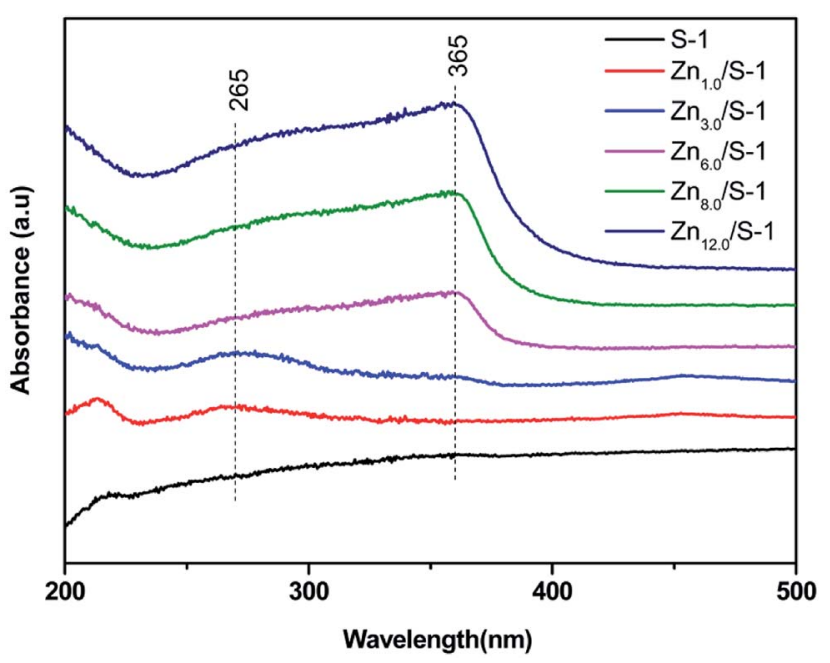

Fig. 2 UV-Vis spectra of $Z n_{x} / S-1$ ( $x$ from 0.0 to 12.0). 

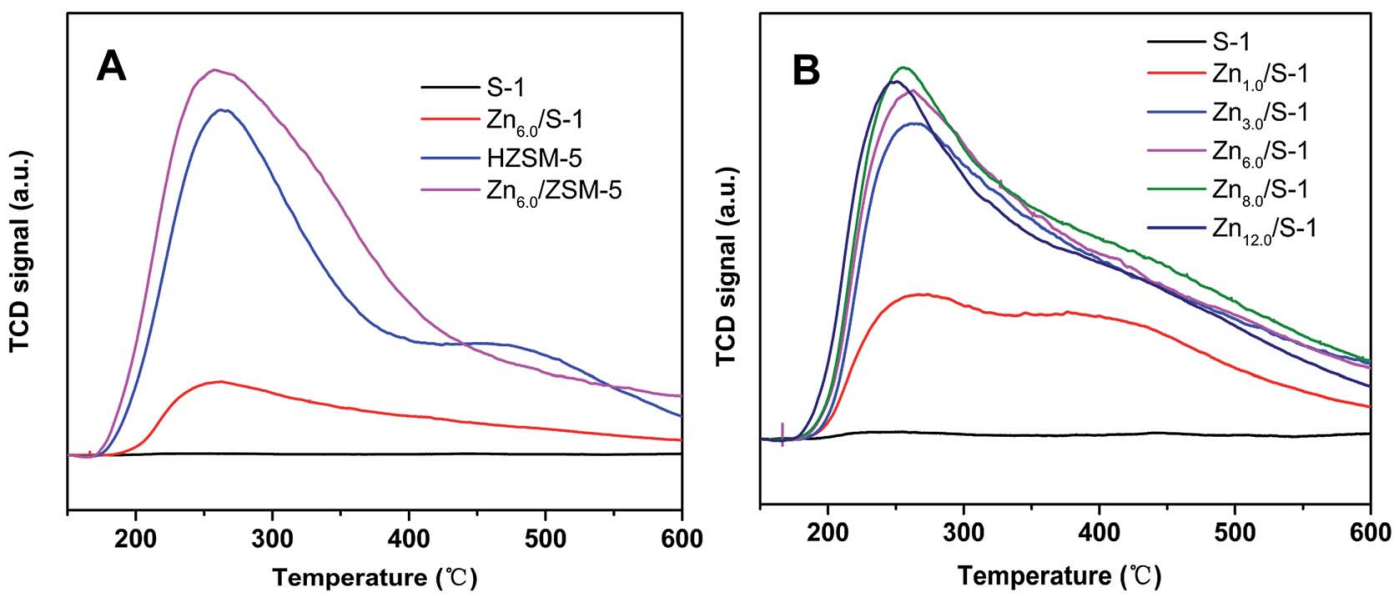

Fig. $3 \mathrm{NH}_{3}$-TPD profiles of (A) S-1, Zn $\mathrm{n}_{6.0} / \mathrm{S}-1, \mathrm{HZSM}-5$ and $\mathrm{Zn}_{6.0} / \mathrm{HZSM}-5$, and (B) the series $\mathrm{Zn} \times \mathrm{S}-1$ ( $x$ from 0.0 to 12.0 ) samples.

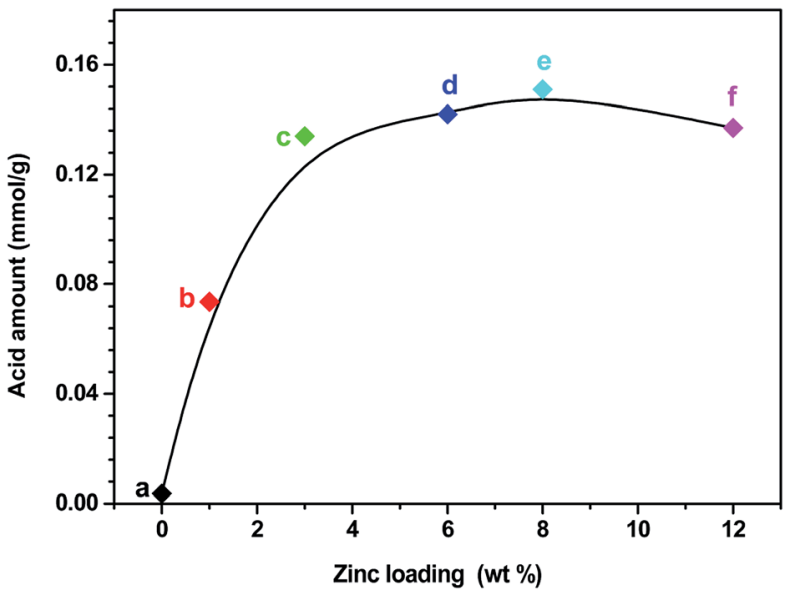

Fig. 4 The relevance of $Z n$ loading and acid amount of $S-1$ (a), $Z n_{1.0} / S-$ 1 (b), $Z_{3.0} / \mathrm{S}-1$ (c), $\mathrm{Zn}_{6.0} / \mathrm{S}-1$ (d), $\mathrm{Zn}_{8.0} / \mathrm{S}-1$ (e) and $\mathrm{Zn}_{12.0} / \mathrm{S}-1$ (f), respectively. acid sites, but also raised some Brønsted acid sites in $\mathrm{Zn}_{x} / \mathrm{S}-1$ catalysts, as disclosed by the two $\mathrm{N}-\mathrm{H}$ stretching signals. Furthermore, we further detected variations in the spectra with heating and evacuation procedures, as shown in Fig. 6. The bands at 3290,3220 , and $3190 \mathrm{~cm}^{-1}$ almost disappeared after evacuation at $450{ }^{\circ} \mathrm{C}$ for $30 \mathrm{~min}$, suggesting the acid sites of $\mathrm{Zn}_{x} /$ $\mathrm{S}-1$ were mostly weak to medium. This was in good agreement with the $\mathrm{NH}_{3}$-TPD results.

\subsection{Origin of $\mathrm{Zn}_{x} / \mathrm{S}-1$ acidity}

3.3.1 Lewis acid sites in $\mathbf{Z n}_{\boldsymbol{x}} / \mathbf{S}$-1. It is generally accepted that $\mathrm{Zn}$ species $^{\mathbf{1 4 - 1 6 , 3 0 , 3 1}}$ can provide Lewis acid sites in $\mathrm{Zn}$ modified ZSM-5 or beta zeolite. Similarly, we speculated that the Lewis acid sites in $\mathrm{Zn}_{x} / \mathrm{S}-1$ were also associated with their $\mathrm{Zn}$ species. UV-Vis spectra and FT-IR spectroscopy of adsorbed CO results showed that $\mathrm{Zn} / \mathrm{S}-1$ contained two $\mathrm{Zn}$ species: small $\mathrm{ZnO}$ clusters inside the pore and large $\mathrm{ZnO}$ crystals on the external surface. ${ }^{15}$ Therefore, the Lewis acid sites of $\mathrm{Zn}_{x} / \mathrm{S}-1$ should be provided by $\mathrm{ZnO}$ clusters or large $\mathrm{ZnO}$ crystals. The UV-Vis
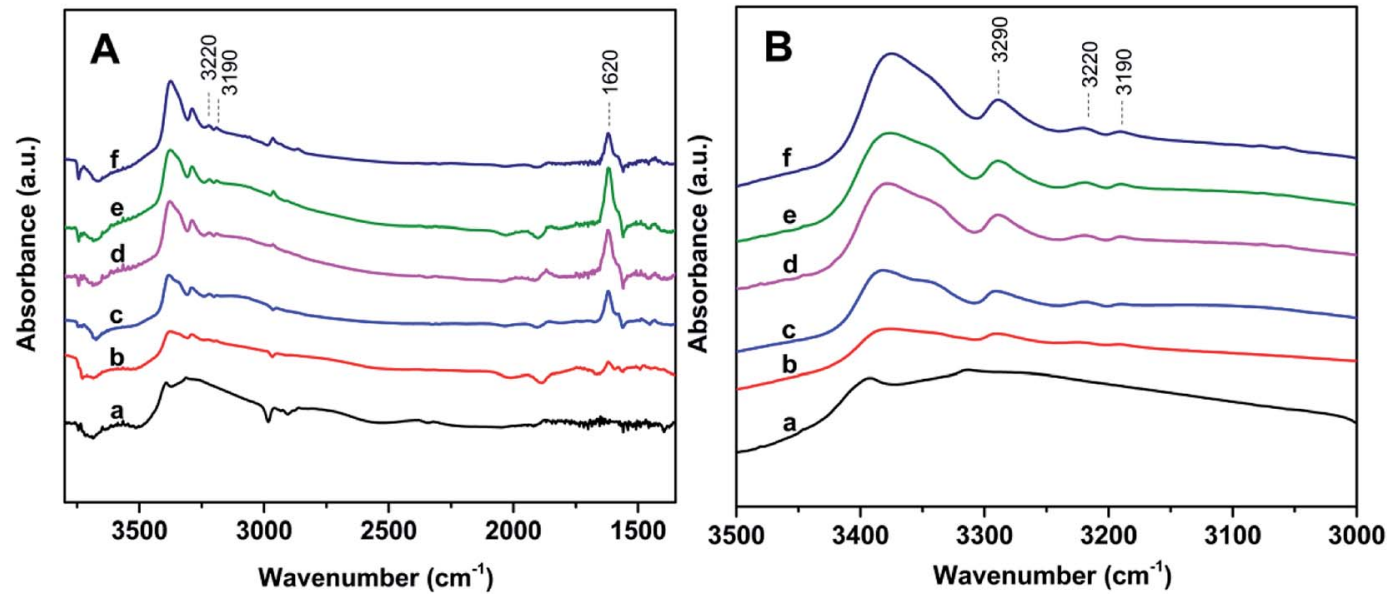

Fig. 5 Ammonia-adsorbed FT-IR spectra (A) and the magnified spectra in the NH-stretching region (B) of the series $Z n_{6.0} / S-1 Z n_{x} / S-1$ samples: (a) S-1, (b) $Z n_{1.0} / S-1$, (c) $Z n_{3.0} / S-1$, (d) $Z n_{6.0} / S-1$, (e) $Z n_{8.0} / S-1$ and (f) $Z n_{12.0} / S-1$. 


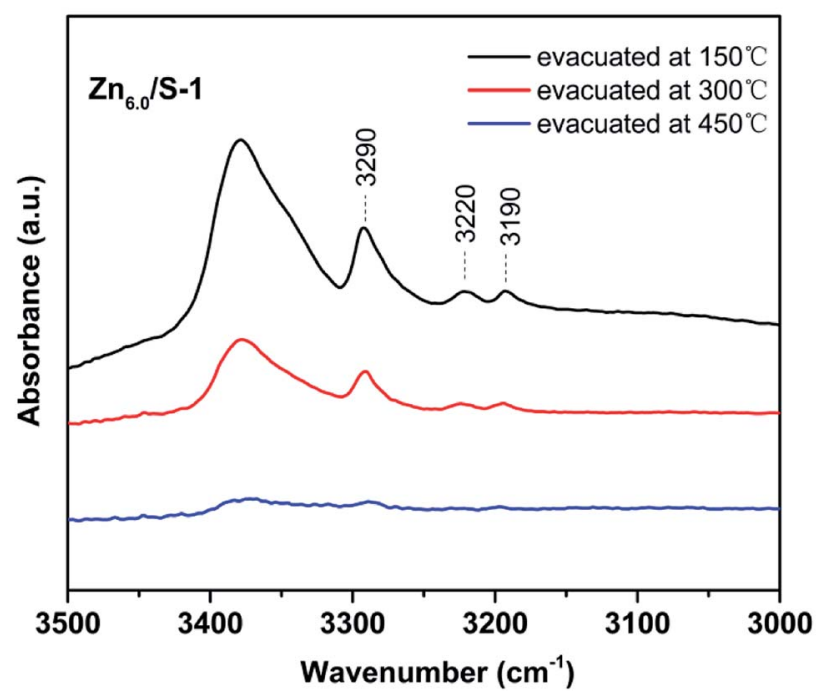

Fig. 6 Ammonia-adsorbed FT-IR spectra of $\mathrm{Zn}_{6.0} / \mathrm{S}-1$ in the $\mathrm{NH}$ stretching region after evacuation at 150,300 and $450{ }^{\circ} \mathrm{C}$ for $30 \mathrm{~min}$.

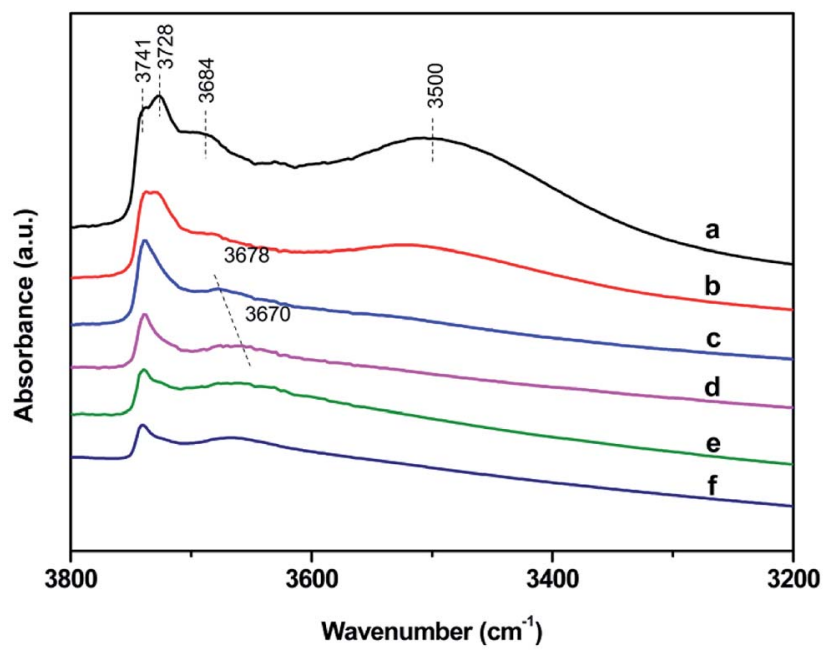

Fig. 7 Infrared hydroxyl stretching region of S-1 (a), $Z n_{1.0} / S-1$ (b), $Z_{3.0} / S-1$ (c), $Z n_{6.0} / S-1$ (d), $Z n_{8.0} / S-1$ (e) and $Z n_{12.0} / S-1$ (f). Catalysts have been dehydrated at $400{ }^{\circ} \mathrm{C}$ for $4 \mathrm{~h}$.

spectra (Fig. 2) showed that subnanometer ZnO clusters inside zeolite pores were the primary $\mathrm{Zn}$ species in $\mathrm{Zn}_{x} / \mathrm{S}-1$ at low $\mathrm{Zn}$ loadings. In addition to $\mathrm{ZnO}$ clusters, most large $\mathrm{ZnO}$ crystals were generated on the external surface when the $\mathrm{Zn}$ loadings were much higher. In contrast, as shown in Fig. 5A, the ammonia-adsorbed FT-IR spectra clearly indicated a similar change in the quantity of Lewis acid sites of $\mathrm{Zn}_{x} / \mathrm{S}-1$ with the change in peak intensity at $1618 \mathrm{~cm}^{-1}$. The Lewis acid amount in $\mathrm{Zn}_{x} / \mathrm{S}-1$ increased dramatically with increasing $\mathrm{Zn}$ loading at low loadings (below $3.0 \mathrm{wt} \%$ ). This increasing trend slowed as the $\mathrm{Zn}$ loading was increased from $3.0 \mathrm{wt} \%$ to $8.0 \mathrm{wt} \%$, and then began to decrease when the $\mathrm{Zn}$ loading reached $12.0 \mathrm{wt} \%$. From both UV-Vis and ammonia-adsorbed FT-IR spectra, it was easy to conclude that subnanometer $\mathrm{ZnO}$ clusters inside $\mathrm{S}-1$ zeolite pores were the major contributors of Lewis acid sites in $\mathrm{Zn}_{x} / \mathrm{S}-1$ catalysts.

3.3.2 Brønsted acid sites in $\mathrm{Zn}_{x} / \mathbf{S}-\mathbf{1}$. As shown in the hydroxyl stretching vibration region of the FT-IR spectra (Fig. 7), S-1 zeolite contained isolated silanol groups exposed on the external surface $\left(3741 \mathrm{~cm}^{-1}\right)$, terminal silanol groups located in the internal cavities $\left(3728 \mathrm{~cm}^{-1}\right)$, abundant $\mathrm{H}$-bonded silanols in internal defects as linear chains and/or rings of hydroxylated species $\left(3500 \mathrm{~cm}^{-1}\right)$, and vicinal silanols inside internal pores $\left(3684 \mathrm{~cm}^{-1}\right) .^{1,2}$ The appearance of these silanol groups indicated the presence of a large number of defect sites in S-1 zeolite. When S-1 zeolite was modified with $\mathrm{Zn}$, these internal silanol groups (bands at 3728, 3684, and $3500 \mathrm{~cm}^{-1}$ ) and some of the isolated silanol groups $\left(3741 \mathrm{~cm}^{-1}\right)$ exposed at the external surface of S-1 zeolite were found to be dramatically diminished, suggesting that some $\mathrm{Zn}$ species in $\mathrm{Zn}_{x} / \mathrm{S}-1$ strongly interacted with the defect sites. Furthermore, a new band at $3678 \mathrm{~cm}^{-1}$ was observed in $\mathrm{Zn}_{3.0} / \mathrm{S}-1$, and redshifted to $3670 \mathrm{~cm}^{-1}$ when the $\mathrm{Zn}$ loading was increased from 6.0 to 12.0 , which was likely due to the formation of external $\mathrm{Zn}-\mathrm{OH}$ groups on the $\mathrm{ZnO}$ clusters. ${ }^{15}$

FT-IR spectra of surface hydroxyl groups with ammonia absorption were also measured to probe the Brønsted acid sites of $\mathrm{Zn}_{x} / \mathrm{S}-1$. To avoid disturbance from hydrogen-bonded species formed by the interaction of $\mathrm{NH}_{3}$ and intrinsic hydroxyl groups in S-1 zeolite, as shown in Scheme $1,{ }^{1}$ the ammonia-adsorbed catalysts were evacuated at $150{ }^{\circ} \mathrm{C}$ for $30 \mathrm{~min}$. After $\mathrm{Zn}$ modification, both Lewis and Brønsted acid sites were found in $\mathrm{Zn}_{x} / \mathrm{S}-1$ $(x=1.0-6.0)$, as shown in the $(\mathrm{NH})$ stretching region in Fig. 8B. This result was consistent with the ammonia-adsorbed FT-IR spectra (Fig. 5). In contrast, it was interpreted from Fig. 8A that the residual signals $\left(\nu=3741,3728\right.$, and $\left.3500 \mathrm{~cm}^{-1}\right)$ of silicon hydroxyl groups in $\mathrm{Zn}_{x} / \mathrm{S}-1$ would hardly be disturbed after $\mathrm{NH}_{3}$ adsorption, indicating that they had no effect on the acidity of $\mathrm{Zn}_{x} / \mathrm{S}-1$. Notably, the bands at 3678 and $3670 \mathrm{~cm}^{-1}$, corresponding to $\mathrm{Zn}-\mathrm{OH}$ groups on $\mathrm{ZnO}$ clusters, were significantly consumed after $\mathrm{NH}_{3}$ adsorption. The consumption of these silanol group bands at 3678 and $3670 \mathrm{~cm}^{-1}$ clearly demonstrated that the $\mathrm{Zn}-\mathrm{OH}$ groups were associated with<smiles>[CH2]NCO[Si](C)(C)C</smiles>

Scheme 1 

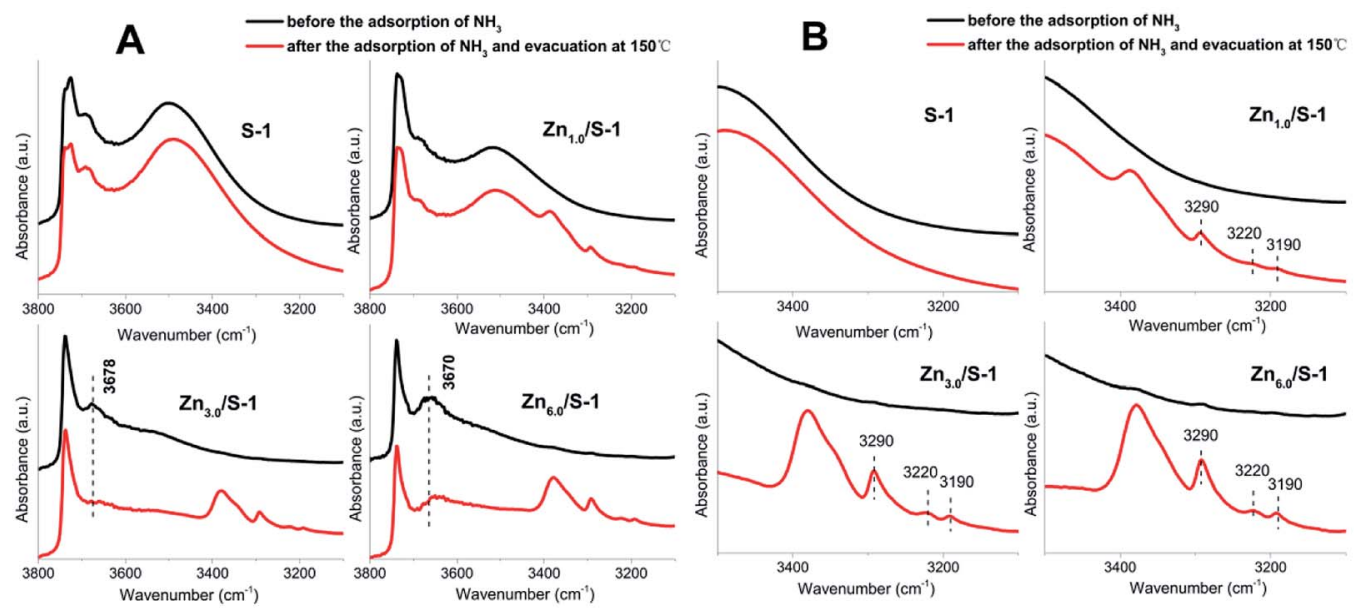

Fig. 8 (A) IR spectra in the $\nu(\mathrm{OH})$ and $\nu(\mathrm{NH})$ stretching region of $\mathrm{Zn}_{x} / \mathrm{S}-1$ ( $x$ from 0.0 to 6.0 ) before and after the adsorption of $\mathrm{NH}_{3}$, respectively; (B) corresponding magnified IR spectra in the $\nu(\mathrm{NH})$ stretching region.

Brønsted acid sites of $\mathrm{Zn}_{x} / \mathrm{S}-1$. To our knowledge, this relationship between Brønsted acid sites and $\mathrm{Zn}-\mathrm{OH}$ groups on $\mathrm{ZnO}$ clusters of $\mathrm{Zn} / \mathrm{S}-1$ is reported here for the first time.

\subsection{Catalytic performance}

The catalytic conversion of isobutane was tested in a microscale fixed-bed reactor and the results are shown in Table 2. As an effective strategy, Zn modification significantly enhanced the catalytic activity of S-1 zeolite. At $550{ }^{\circ} \mathrm{C}$ and atmospheric pressure, the parent S-1 zeolite was completely inactive for isobutane transformation. However, under the same reaction conditions, $\mathrm{Zn}_{x} / \mathrm{S}-1$ catalysts exhibited promoted isobutane conversion rates. In particular, the $\mathrm{Zn}_{1.0} / \mathrm{S}-1$ and $\mathrm{Zn}_{3.0} / \mathrm{S}-1$ catalysts led to $27.5 \%$ and $60.2 \%$ isobutane conversion, respectively. As the $\mathrm{Zn}$ content was increased (from 3.0 to $8.0 \mathrm{wt} \%)$, the isobutane conversion continued increasing, reaching a maximum isobutane conversion of $66.7 \%$. However, a slight downward tendency in isobutane conversion was observed when the Zn loading reached $12.0 \mathrm{wt} \%$. Despite this, the $\mathrm{Zn}_{12.0} / \mathrm{S}-1$ catalyst still afforded a good isobutane conversion of $65.5 \%$. Moreover, according to the literature, ${ }^{32}$ the iso-butane activity of $\mathrm{Zn}_{x} / \mathrm{S}-1 \quad(27.5-66.7 \%)$ obtained under our experimental conditions is close to that of the commercial $\mathrm{Cr}_{2} \mathrm{O}_{3} / \mathrm{Al}_{2} \mathrm{O}_{3}$ catalyst (48-65\%).

Among the products of isobutane transformation over $\mathrm{Zn}_{x} / \mathrm{S}$ 1 catalysts, isobutene was the primary component (about 60\%), indicating that $\mathrm{Zn}$ modification imparted the catalysts impressive dehydrogenation functions. Furthermore, the presence of substantial amounts of 1-butene and cis/trans-2-butene among the products indicated that the Brønsted acid sites provided by the $\mathrm{Zn}-\mathrm{OH}$ groups in S-1 zeolite also played an important role in isobutene isomerization. A high selectivity of isobutene and its isomers ranging from 84.6 to 97.2 was achieved on the catalyst with different $\mathrm{Zn}$ loading. Moreover, a small amounts of aromatic products (less than $8 \%$ ), due to aromatization over the $\mathrm{Zn}$ species, and cracked lower hydrocarbon products $\left(\mathrm{C}_{1}-\mathrm{C}_{3}\right.$, much less than $8 \%$ ) were formed because the Brønsted acid strength of $\mathrm{Zn}_{x} / \mathrm{S}-1$ was still relatively weak. In comparison, when isobutane transformation was conducted over the $\mathrm{Zn}_{6.0}$ / HZSM-5 catalyst, the isobutane conversion rated was nearly $100 \%$, with aromatics obtained as the major product (more than $50 \%$ ). This reaction also produced a large amount of undesired cracking components (over $40 \%$ ), which comprised dry gas $\left(\mathrm{C}_{1}+\mathrm{C}_{2}\right)$ and propane in a $2: 1$ ratio. In contrast, the

Table 2 The catalytic performance of iso-butane transformations over S-1, Zn $\mathrm{n}_{x} / \mathrm{S}-1$ and $\mathrm{Zn}_{6.0} / \mathrm{ZSM}-5$ catalysts ${ }^{a}$

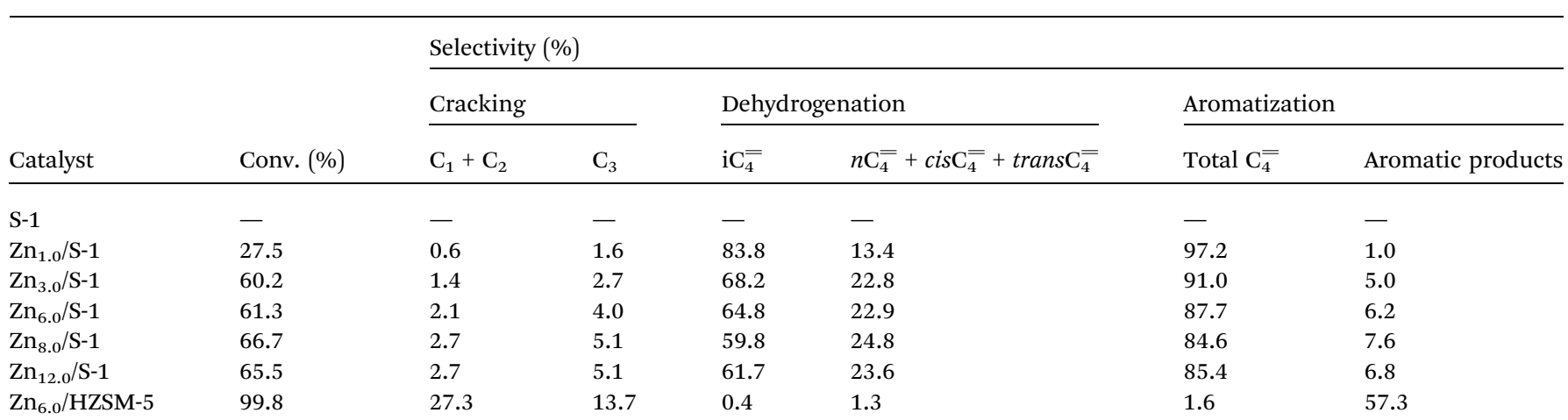

${ }^{a}$ Catalyst loading $200 \mathrm{mg}$, reactions temperature $550{ }^{\circ} \mathrm{C}$, GHSV $1200 \mathrm{~h}^{-1}$, iso-butane feedstock compositions: iso-butane : $\mathrm{N}_{2}=50: 50(\mathrm{v} / \mathrm{v})$, the results were obtained after $1 \mathrm{~h}$ of testing. 

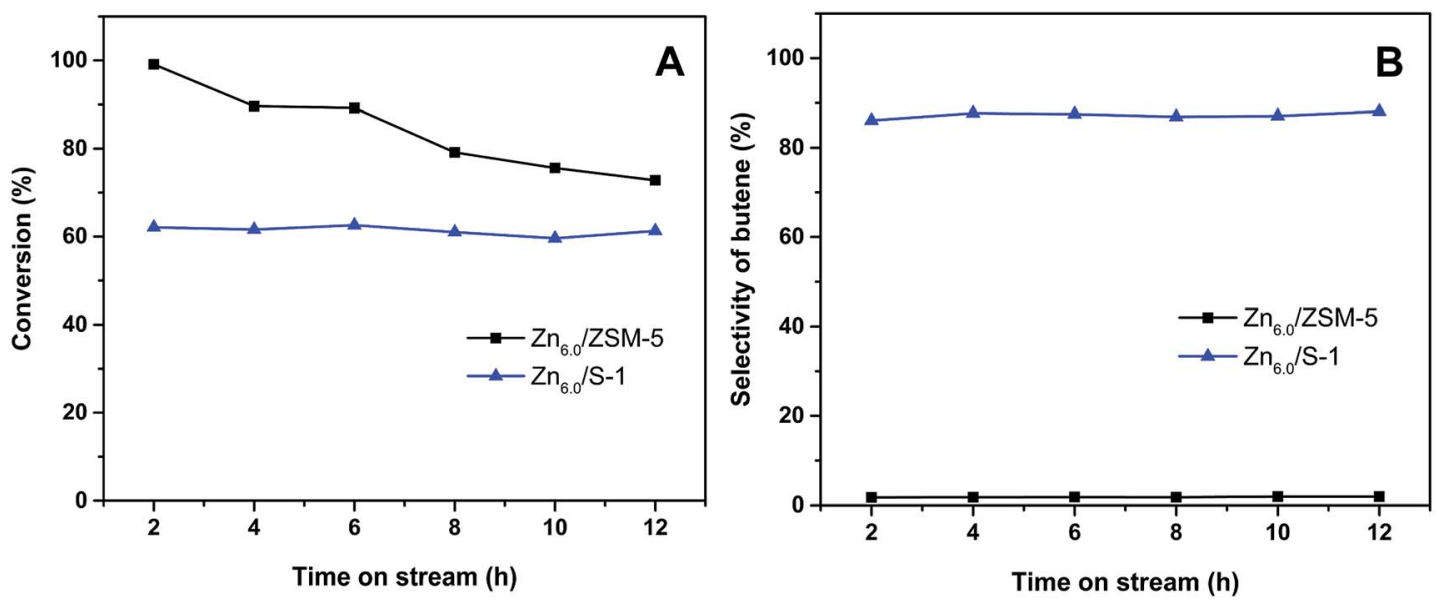

Fig. 9 (A) Conversion of iso-butane and (B) selectivity of butene as a function of reaction time over $Z \mathrm{n}_{6.0} / \mathrm{ZSM}-5$ and $Z \mathrm{n}_{6.0} / \mathrm{S}-1$ catalysts.

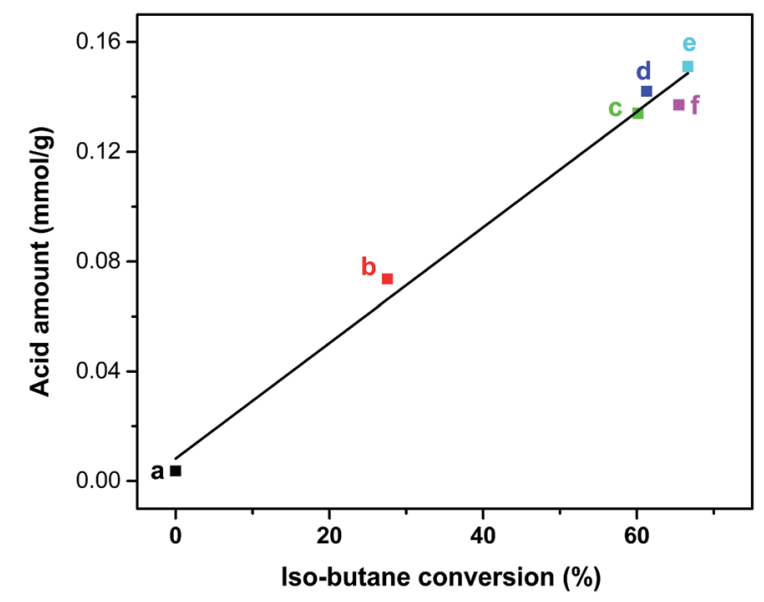

Fig. 10 The relevance between iso-butane conversion and the acid amount of S-1 (a), Zn $\mathrm{n}_{1.0} / \mathrm{S}-1$ (b), $Z \mathrm{n}_{3.0} / \mathrm{S}-1$ (c), $Z \mathrm{n}_{6.0} / \mathrm{S}-1$ (d), $Z \mathrm{n}_{8.0} / \mathrm{S}-1$ (e) and $Z_{12.0} / \mathrm{S}-1$ (f), respectively. (The acid amounts of catalysts were determined by $\mathrm{NH}_{3}-\mathrm{TPD}$ ).

sum of dry gas and propane byproducts was efficiently suppressed over appropriately modified $\mathrm{Zn}_{x} / \mathrm{S}-1$ catalysts.

The stability of $\mathrm{Zn} / \mathrm{S}-1$ catalyst in the conversion of isobutane was further investigated. As shown in Fig. 9A, slight deactivation was observed over $\mathrm{Zn}_{6.0} / \mathrm{S}-1$ catalyst during the lifespan of $12 \mathrm{~h}$. However, for $\mathrm{Zn}_{6.0} / \mathrm{HZSM}-5$ catalyst, the conversion decreased from $99.1 \%$ to $72.8 \%$ after $12 \mathrm{~h}$. On the other hand, the selectivity of total butene was well-preserved over $\mathrm{Zn}_{6.0} / \mathrm{S}-1$ catalyst during the $12 \mathrm{~h}$ examination (Fig. 9B). These results indicated that $\mathrm{Zn}_{x} / \mathrm{S}-1$ catalysts obtain extraordinary stability in the iso-butane dehydrogenation system. Furthermore, as previously reported, ${ }^{19-21}$ zinc titanate and $\mathrm{Zn} /$ $\mathrm{SiO}_{2}$ catalysts also had been considered as the candidates for light alkanes dehydrogenation. However, the zinc titanate catalyst deactivated rapidly when both the selectivity and conversion were kept at a higher level. ${ }^{19,20} \mathrm{Zn} / \mathrm{SiO}_{2}$ catalyst exhibited high propylene selectivity in the dehydrogenation of propane.${ }^{21}$ However, the stability is also a big challenge for the industrial applications of $\mathrm{Zn} / \mathrm{SiO}_{2}$ catalyst since the activity can only maintain nearly $50 \%$ of the initial value during $12 \mathrm{~h}$ test. Therefore, $\mathrm{Zn}_{x} / \mathrm{S}-1$ catalysts exhibited both higher activity and excellent stability in comparison with zinc titanate and $\mathrm{Zn} / \mathrm{SiO}_{2}$ catalysts in the dehydrogenation of alkanes.

By correlating the isobutane conversion rates with the acid amount of $\mathrm{Zn}_{x} / \mathrm{S}-1$ (determined by the $\mathrm{NH}_{3}$-TPD method), we obtained a linear dependence of isobutane conversion on the total acid amount of $\mathrm{Zn}_{x} / \mathrm{S}-1$ (Fig. 10). This meant that the acid sites of $\mathrm{Zn}_{x} / \mathrm{S}-1$ played a critical role in isobutane conversion. The yield of undesired dry gases was significantly suppressed, perhaps due to the absence of strong acid sites. Furthermore, the true role of different categories of acid sites of $\mathrm{Zn}_{x} / \mathrm{S}-1$ in isobutane conversion still needs to be identified, with investigations currently underway in our laboratory.

\section{Conclusions}

In summary, the inert S-1 zeolite was significantly acidified by modification with $\mathrm{Zn}$. Both Lewis acid sites and a small amount of Brønsted acid sites were identified in $\mathrm{Zn}_{x} / \mathrm{S}-1$ catalysts. Using UV-Vis and FT-IR analysis, we found that the Lewis and Brønsted acid sites of $\mathrm{Zn}_{x} / \mathrm{S}$ - 1 were associated with small $\mathrm{ZnO}$ clusters and external $\mathrm{Zn}-\mathrm{OH}$ groups on $\mathrm{ZnO}$ clusters, respectively. Furthermore, the linear relationship between isobutane conversion and total acid amount suggested that the acid sites of $\mathrm{Zn}_{x} / \mathrm{S}-1$ played a crucial role in isobutene conversion. $\mathrm{Zn}_{x} / \mathrm{S}-1$ catalysts exhibited excellent isobutane dehydrogenation and butene isomerization activities, and the yield of undesired dry gas (methane and ethane) was significantly suppressed because strong acid sites were absent. A high selectivity of total butene products ranging from 84.6 to 97.2 was achieved on the catalysts with different Zn loading. Therefore, Zn-modified S-1 zeolites can be applied to the highly efficient transformation of light alkanes.

\section{Conflicts of interest}

The authors have no conflicts of interest to declare. 


\section{Acknowledgements}

This work was supported by National Natural Science Foundation of China (No. 21603023).

\section{Notes and references}

1 V. Bolis, C. Busco, S. Bordiga, P. Ugliengo, C. Lamberti and A. Zecchina, Appl. Surf. Sci., 2002, 196, 56-70.

2 G. P. Heitmann, G. Dahlhoff and W. F. Hölderich, J. Catal., 1999, 186, 12-19.

3 H. Ichihashi and H. Sato, Appl. Catal., A, 2001, 221, 359-366.

4 H. Ichihashi, M. Ishida, A. Shiga, M. Kitamura, T. Suzuki, K. Suenobu and K. Sugita, Catal. Surv. Asia, 2003, 7(4), 261-270.

5 B. Bonelli, L. Forni, A. Aloise, J. B. Nagy, G. Fornasari, E. Garrone, A. Gedeon, G. Giordano and F. Trifirò, Microporous Mesoporous Mater., 2007, 101, 153-160.

6 E. Janiszewska, A. Macario, J. Wilk, A. Aloise, S. Kowalak, J. B. Nagy and G. Giordano, Microporous Mesoporous Mater., 2013, 182, 220-228.

7 M. Bernaue, E. Tabor, V. Pashkova, D. Kaucký, Z. Sobalík, B. Wichterlová and J. Dedecek, J. Catal., 2016, 344, 157-172. 8 L. B. Young, S. A. Butter and W. W. Kaeding, J. Catal., 1982, 76(2), 418-432.

9 S. Ilias and A. Bhan, J. Catal., 2014, 311, 6-16.

10 Y. Ni, A. Sun, X. Wu, G. Hai, J. Hu, T. Li and G. Li, Microporous Mesoporous Mater., 2011, 143(2), 435-442.

11 M. Guisnet, N. S. Gnep, D. Aittaleb and Y. J. Doyemetet, Appl. Catal., A, 1992, 87(2), 255-270.

12 J. J. H. B. Sattler, J. Ruiz-Martinez, E. Santillan-Jimenez and B. M. Weckhuysen, Chem. Rev., 2014, 114(20), 10613-10653.

13 T. Otroshchenko, J. Radnik, M. Schneider, U. Rodermerck, D. Linke and E. V. Kondratenko, Chem. Commun., 2016, 52, 8164-8167.

14 J. A. Biscardi, G. D. Meitzner and E. Iglesia, J. Catal., 1998, 179, 192-202.

15 Y. G. Kolyagin, V. V. Ordomsky, Y. Z. Khimyak, A. I. Rebrovc, F. Fajulad and I. I. Ivanova, J. Catal., 2006, 238, 122-133.
16 Y. G. Kolyagin, I. I. Ivanova and Y. A. Pirogov, Solid State Nucl. Magn. Reson., 2009, 35, 104-112.

17 G. Caeiro, R. H. Carvalho, X. Wang, M. A. N. D. A. Lemosa, F. Lemosa, M. Guisnet and F. R. Ribeiro, J. Mol. Catal. A: Chem., 2006, 255, 131-158.

18 Y. J. Ren, F. Zhang, W. M Hua, Y. H Yue and Z. Gao, Catal. Today, 2009, 148, 316-322.

19 A. W. Aldag and B. Okla, US pat. 4,524,144, 1985.

20 Z. X. Chen, A. Derking, W. Koot and M. P. van Dijk, J. Catal., 1996, 161, 730-741.

21 N. M. Schweitzer, B. Hu, U. Das, H. Kim, L. A. Curtiss, P. C. Stair, T. Miller and A. S. Hock, ACS Catal., 2014, 4, 1091-1098.

22 L. Q. Wang, X. S. Wang and X. W. Guo, Chin. J. Catal., 2001, 22, 513-514.

23 J. Chen, Z. Feng, P. Ying and C. Li, J. Phys. Chem. B, 2004, 108, 12669-12676.

24 Y. M. Ni, W. Y. Peng, A. M. Sun, W. L. Mo, J. L. Hu, T. Li and G. X. Li, J. Ind. Eng. Chem., 2010, 16, 503-505.

25 H. A. Zaidi and K. K. Pant, Catal. Today, 2004, 96, 155-160.

26 F. Yin, A. L. Blumenfeld, V. Gruver and J. J. Fripiat, J. Phys. Chem. B, 1997, 101, 1824-1830.

27 W. Zhang, P. G. Smirniotis, M. Gangoda and R. N. Bose, J. Phys. Chem. B, 2000, 104, 4122-4129.

28 V. S. Escribanoa, T. Montanarib and G. Busca, Appl. Catal., B, 2005, 58, 19-23.

29 G. V. A. Martins, G. Berlie, C. Bisio, S. Coluccia, H. O. Pastore and L. Marchese, J. Phys. Chem. C, 2008, 112, 7193-7200.

30 E.-M. El-Malki, R. A. van Santen and W. M. H. Sachtler, J. Phys. Chem. B, 1999, 103, 4611-4622.

31 S. S. Arzumanov, A. A. Gabrienko, D. Freude and A. G. Stepanov, Solid State Nucl. Magn. Reson., 2009, 35, 113-119.

32 K. J. Caspary, H. Gehrke, M. Heinritz-Adrian and M. Schwefer, Handbook of Heterogeneous Catalysis, Wiley, 2nd edn, 2008, pp. 3206-3229. 